\title{
PRODUCTIVE VIABILITY AND PROFITABILITY OF CARROT-COWPEA INTERCROPPING USING DIFFERENT AMOUNTS OF Calotropis procera ${ }^{1}$
}

\author{
FRANCISCO BEZERRA NETO ${ }^{2}$, MAIELE LEANDRO DA SILVA ${ }^{3}$, JAILMA SUERDA SILVA DE LIMA ${ }^{2 *}$, \\ AURÉLIO PAES BARROS JÚNIOR ${ }^{2}$, ITALO NUNES SILVA², ARIDÊNIA PEIXOTO CHAVES ${ }^{2}$
}

\begin{abstract}
Intercropping system and the use of green manure with spontaneous species has been an alternative farming method applied to the productive sector of vegetables in the northeastern semi-arid region. The objective of this work was to determine which amount of Calotropis procera must be incorporated into the soil to provide the highest productive performance of the component crops and increase the profitability of the carrot and cowpea intercropping. The experimental design used was randomized complete blocks with five replicates. The treatments consisted of four amounts of $C$. procera incorporated into the soil: 10, 25, 40 and 55 $\mathrm{t} \mathrm{ha}^{-1}$ on a dry basis. The characteristics evaluated in this intercropping system were: commercial productivity of carrot roots, yield of cowpea green grains, land equivalent ratios for component crops and for the intercropped system, score of the canonical variable of the association, and the economic indicators of gross income, net income, rate of return, and net profit margin. The maximum agronomic efficiency of the carrot $\mathrm{x}$ cowpea intercropping was reached at the land equivalent ratio of 1.12 , using $43.39 \mathrm{tha}^{-1}$ of C. procera biomass incorporated in the soil, while the maximum economic efficiency of the carrot and cowpea crops association was obtained at the net income of $\mathrm{R} \$ 17,856.43 \mathrm{ha}^{-1}$, in the amount of $40.60 \mathrm{t} \mathrm{ha}^{-1}$ of $C$. procera biomass added to the soil.
\end{abstract}

Keywords: Calotropis procera. Daucus carota. Green manure. Vigna unguiculata. Intercropping.

\section{VIABILIDADE PRODUTIVA E RENTABILIDADE DO CONSÓRCIO CENOURA x CAUPI USANDO DIFERENTES QUANTIDADES DE Calotropis procera}

\begin{abstract}
RESUMO - Sistema consorciado e uso de adubação verde com espécies espontâneas tem sido um método alternativo de cultivo aplicado ao setor produtivo de hortaliças na região semiárida nordestina. O objetivo deste trabalho foi determinar qual quantidade de Calotropis procera deve ser incorporada ao solo para proporcionar o melhor desempenho produtivo das culturas componentes e aumentar a rentabilidade do consórcio de cenoura e caupi. O delineamento experimental utilizado foi de blocos completos casualizados com cinco repetições. Os tratamentos consistiram de quatro quantidades de C. procera incorporadas ao solo: 10, 25, 40 e $55 \mathrm{t} \mathrm{ha}^{-1}$, em base seca. As características avaliadas neste sistema consorciado foram: produtividade comercial de raízes de cenoura, produtividade de grãos verdes de caupi, índices de uso eficiente da terra das culturas componentes e do consórcio, escore da variável canônica da associação e os indicadores econômicos renda bruta, renda líquida, taxa de retorno e margem de lucro líquido. A máxima eficiência agronômica do consórcio cenoura $\mathrm{x}$ caupi foi alcançada no índice de uso eficiente da terra de 1,12 , utilizando-se $43,39 \mathrm{t} \mathrm{ha}^{-1}$ de biomassa de $C$. procera incorporada ao solo, enquanto a eficiência econômica máxima da associação cenoura x caupi foi obtida com a renda líquida de $\mathrm{R} \$ 17.856,43 \mathrm{ha}^{-1}$, na quantidade de $40,60 \mathrm{tha}^{-1}$ de biomassa de $C$. procera adicionada ao solo.
\end{abstract}

Palavras-chave: Calotropis procera. Daucus carota. Adubo verde. Vigna unguiculata. Consorciação de culturas.

\footnotetext{
*Corresponding author

${ }^{1}$ Received for publication in 05/24/2017; accepted in 06/01/2018.

Paper extracted from a National Post-Doctoral Program supervised by the first author

${ }^{2}$ Department of Agronomic and Forest Sciences, Universidade Federal Rural do Semi-Árido, Mossoró, RN, Brazil; bezerra@ufersa.edu.br - ORCID: 0000-0001-9622-206X, jailma@ufersa.edu.br - ORCID: 0000-0001-7584-592X, aurelio.barros@ufersa.edu.br - ORCID: 00000002-6983-8245, italonunessilva@gmail.com - ORCID: 0000-0003-0954-1260, aridenia.peixoto@hotmail.com - ORCID: 0000-00022184-2536.

${ }^{3}$ Department of Agronomy, Universidade Estadual de Mato Grosso do Sul, Aquidauana, MS, Brazil; maiele_engenharia@yahoo.com.br ORCID: 0000-0002-7063-5138.
} 


\section{INTRODUCTION}

Carrot (Daucus carota L.) intercropping with cowpea [(Vigna unguiculata L. (Walp)] is beginning to be implemented in the state of Rio Grande do Norte, Brazil, and there is almost no information about the viability and profitability of this cultivation system nor information about the post-harvest quality of the products of the component cultures. It is known, however, that intercropping reduces the use of agricultural inputs, establishes a greater dynamism in the agrosystem, increases yields of crops, and contributes to an improved regularity of the food supply (RUSINAMHODZI et al., 2012).

The efficiency of an intercropped system is mainly based on the complementarity between the crops involved, being that the results will be greater, to the extent to which one can minimize the established effects of one species on the other (PORTO et al., 2011). The cowpea is one of the main legumes of economic value cultivated in the northeastern semi-arid region that can complement the carrot culture, also of high economic and nutritional value in an intercropping system, since it has an architecture and radicular system different from the carrot. This legume is consumed in the form of a green pod, where its green grains, called green beans, are the raw material for a range of regional dishes, as well as being used as green manure (SANTOS et al., 2009). When grown for consumption as fresh grains it is treated as a vegetable, hence it is called cowpea-vegetable (COSTA et al., 2017).

In production systems with tuberous vegetables (e.g., carrot), manure has been the traditional input used by producers. Its use has generated dependence on external sources and increased the cost of production on the property. Thus, the use of alternative inputs, such as green manuring, may allow the substitution of the quantities of manure to be applied and contribute to the replenishment of the nitrogen $(\mathrm{N})$ reserves in the soil (CASTRO et al., 2004).
Among the effects of green manuring on soil fertility is increased organic matter content, increased nutrient availability and effective cation exchange capacity, and decreased aluminum content and nutrient mobilization (CALEGARI et al., 1993). These effects are quite variable and dependent on the species used, the biomass management, the planting season, the green manure cut, and the permanence time of residues in the soil, the local conditions and the interaction between these factors (DELARMELINDA et al., 2010). Thus, it is necessary to adapt the green manuring system for each cultivated vegetable crop, always considering the conditions of soil, climate, and source of available fertilizers.

Spontaneous species of the Caatinga biome as the roostertree [Calotropis procera (Ait.) R. Br.] are being used as green manure in tuberose and leafy vegetables in studies in the semi-arid region of northeast Brazil (SOUZA et al., 2017a,b,c; RIBEIRO et al., 2018). Thus, the objective of this work was to determine which amount of $C$. procera must be incorporated into the soil to provide the highest productive performance of the component crops and increase the profitability of the carrot and cowpea intercropping.

\section{MATERIAL AND METHODS}

The study was conducted from September 2012 to January 2013 on the Rafael Fernandes farm, located in the district of Alagoinha, $20 \mathrm{~km}$ from the municipality of Mossoró, RN ( $5^{\circ} 11^{\prime} \mathrm{S}, 37^{\circ} 20^{\prime} \mathrm{W}$, altitude, $18 \mathrm{~m}$ ), Brazil. The climate is semi-arid and, based on Köppen's climate classification, is type "BShw", namely dry and very hot. The region has two distinctive seasons that include the dry season from June to January and the rainy season from February to May (OLIVEIRA et al., 2012). Figure 1 shows the average meteorological data during the period when the study was conducted.

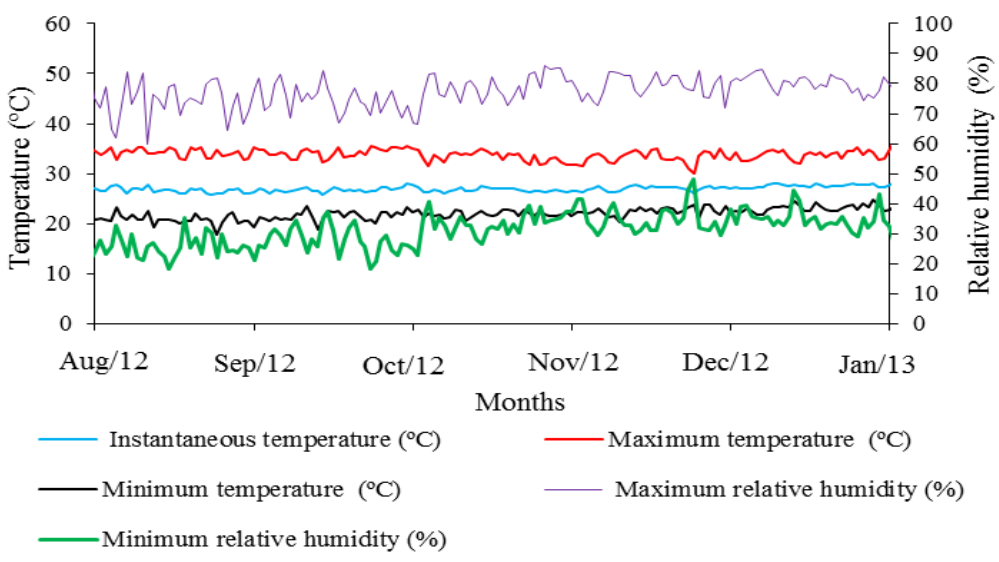

Figure 1. Average values of instantaneous, maximum and minimum temperatures $\left({ }^{\circ} \mathrm{C}\right)$ and of maximum and minimum relative humidity (\%) during the period when the study was conducted. 
Before the installation of the field experiment, simple samples of a Yellow-Red Latosol Argisolic soil with a sandy loam texture were collected and sent for analysis to the Laboratory of Soil Fertility and Plant Nutrition at the Instituto Federal de Educação (Ciência e Tecnologia do Ceará, campus Iguatu), whose results were as follows: $\mathrm{pH}$ (water) $=$ 7.06, O.M. $=7.06 \mathrm{~g} \mathrm{~kg}^{-1}, \mathrm{P}=16.5 \mathrm{mg} \mathrm{dm}$, $\mathrm{K}=55.3 \mathrm{mg} \mathrm{dm}{ }^{-3}, \mathrm{Ca}=1.57 \mathrm{cmol}_{\mathrm{c}} \mathrm{dm}^{-3}$, $\mathrm{Mg}=1.05 \mathrm{cmol}_{\mathrm{c}} \mathrm{dm}^{-3}, \mathrm{Na}=2.05 \mathrm{mg} \mathrm{dm}{ }^{-3}$, sum of bases $=2.32 \mathrm{cmol}_{\mathrm{c}} \mathrm{dm}^{-3}$, cation exchange capacity $(\mathrm{CEC})=2.73 \mathrm{cmol}_{\mathrm{c}} \mathrm{dm}^{-3}$, base saturation $=85 \%$, and electrical conductivity $=2.81 \mathrm{dS} \mathrm{m}^{-1}$.

The experimental design was a randomized complete block with four treatments and five replications. The treatments consisted of the amounts of $C$. procera incorporated into the soil: $10,25,40$ and $55 \mathrm{tha}^{-1}$ on a dry basis.

The intercropping system was established using alternating strips of the component crops in the proportion of $50 \%$ of the area for the cowpea and $50 \%$ for the carrot, and where each plot consisted of four rows of cowpea alternated with four rows of carrot, flanked by two border-rows of carrot on one side and two border-rows of cowpea on the other side, thus constituting the lateral borders. The total area of the plot was $3.60 \mathrm{~m}^{2}$, with a harvest area of $2.00 \mathrm{~m}^{2}$ containing 40 plants of cowpea and 100 carrot plants at the spacing of $0.25 \mathrm{~m}$ between rows. The planted cowpea cultivar was BRS Itaim and the carrot was Brasília.

In each block, single plots of the cowpea and carrot crops were planted to obtain the land equivalent ratio for each crop and of the intercropping system. A single crop of each vegetable was established through the planting of six lines per plot, with a total area of $3.60 \mathrm{~m}^{2}$ and a harvest area of $2.00 \mathrm{~m}^{2}$, with the spacing of $0.50 \mathrm{~m} \mathrm{x}$ $0.10 \mathrm{~m}$ for the cowpea crop and a total area of 1.44 $\mathrm{m}^{2}$ and a harvest area of $0.80 \mathrm{~m}^{2}$, with spacing of $0.20 \mathrm{~m} \times 0.10 \mathrm{~m}$ for the carrot crop. The harvest areas consisted of the four central rows of the plot plants, excluding the first and last plants of each row, which were used as a border.

The soil preparation consisted of mechanical cleaning of the area with the aid of a tractor with a coupled plow, followed by a harrowing and lifting of the beds. A solarization using transparent plastic of 30-micron 'Vulca Brilho Bril Fles' was carried out for 30 days to reduce the soil phytopathogen population, which would affect crop productivity (PEREIRA et al., 2016).

The $C$. procera was collected from the native vegetation of localities near the city of Mossoró, and then crushed into pieces $2-3 \mathrm{~cm}$ in length in a conventional forage machine, and left to dry at room temperature until reaching a content of humidity of $10 \%$. Samples of this green manure were randomly collected for quantification of nutrient contents, and the chemical composition was: $15.3 \mathrm{~g} \mathrm{~kg}^{-1} \mathrm{~N} ; 4.0 \mathrm{~g}$ $\mathrm{kg}^{-1} \mathrm{P} ; 15.7 \mathrm{~g} \mathrm{~kg}^{-1} \mathrm{~K} ; 9.3 \mathrm{~g} \mathrm{~kg}^{-1} \mathrm{Ca} ; 7.03 \mathrm{~g} \mathrm{~kg}^{-1} \mathrm{Mg}$; $601.7 \mathrm{mg} \mathrm{kg}^{-1} \mathrm{Fe} ; 194 \mathrm{mg} \mathrm{kg}^{-1} \mathrm{Mn} ; 31.23 \mathrm{mg} \mathrm{kg}{ }^{-1}$ $\mathrm{Zn} ; 7.8 \mathrm{mg} \mathrm{kg}{ }^{-1} \mathrm{Cu} ; 56.49 \mathrm{mg} \mathrm{kg}^{-1} \mathrm{~B} ; 950.13 \mathrm{mg} \mathrm{kg}^{-1}$ $\mathrm{Na}$, and a $\mathrm{C}: \mathrm{N}$ ratio of $25: 1$.

Two incorporations of the green manure were added to the intercropped and single carrot plots, with $50 \%$ of the $C$. procera amount being incorporated into all plots at 20 days before sowing of the component crops. The remaining $50 \%$ of the $C$. procera was incorporated at 45 days after planting these crops. The incorporation of the green manure in the single crops of cowpea and carrot was of 53.57 and $42.00 \mathrm{t} \mathrm{ha}^{-1}$ respectively, according to the amount already optimized from previous experiments (VIEIRA, 2014).

A micro-sprinkler irrigation system was used, with two daily irrigation shifts, one in the morning and the other in the afternoon, providing a daily water sheet averaging $8 \mathrm{~mm}$ in order to maintain soil moisture between 50 and $70 \%$ of the field capacity, to achieve an ideal condition for the nitrification process (NOVAIS et al., 2007). Weed control was performed by manual weeding.

The planting of the carrot crop was conducted on 10/09/2012 in holes approximately $2 \mathrm{~cm}$ deep, placing two to three seeds per hole. At 23 days after sowing, thinning was performed, leaving one plant per hole. The cowpea was sown on the same date as the carrot and its thinning was carried out 10 days after planting, leaving one plant per hole.

The cowpea harvest began at 56 days after planting (12/03/12) and ended at 71 days after sowing (12/18/2012). The carrot harvest was carried out at 105 days after sowing $(01 / 24 / 2013)$.

The characteristics evaluated were: commercial productivity of carrot roots (CPCR) in intercropping with cowpea $\left(\mathrm{Y}_{\mathrm{ab}}\right)$ and single crop $\left(\mathrm{Y}_{\mathrm{aa}}\right)$, yield of green grains of cowpea (YGGC) in intercropping with carrot $\left(\mathrm{Y}_{\mathrm{ba}}\right)$ and single crop $\left(\mathrm{Y}_{\mathrm{bb}}\right)$, partial land equivalent ratio for carrot (PLERC = $\mathrm{Y}_{\mathrm{ab}} / \mathrm{Y}_{\mathrm{aa}}$ ), for cowpea (PLERCo $=\mathrm{Y}_{\mathrm{ba}} / \mathrm{Y}_{\mathrm{bb}}$ ) and for the system $\left(\mathrm{LER}=\mathrm{Y}_{\mathrm{ab}} / \mathrm{Y}_{\mathrm{aa}}+\mathrm{Y}_{\mathrm{ba}} / \mathrm{Y}_{\mathrm{bb}}\right)$, score of the canonical variable $\mathrm{Z}$ of the intercropping (obtained by bivariate analysis of the data of the production of the vegetable crops in intercropping), and the economic indicators of gross income (GI), net income (NI), rate of return (RR), and net profit margin (NPM).

GI was obtained by the value of production per hectare, based on the price paid to producers in the region in December 2012 for cowpea and January 2013 for carrot. For the carrot, the value paid was R\$ $1.70 \mathrm{~kg}^{-1}$ and for cowpea $\mathrm{R} \$ 6.00 \mathrm{~kg}^{-1}$. Updating the variation of the United States (US) dollar against the Brazilian real, its value was 1 USD $=3.1572$ BRL in January 2018 .

NI was determined by the difference between the GI and the total costs (TC) involved. The TC of production were calculated and determined after the production process but based on the prices charged

Rev. Caatinga, Mossoró, v. 32, n. 1, p. 62 - 71, jan. - mar., 2019 
from September 2012 to January 2013. The RR was obtained from the ratio of GI to TC and NPM, determined by the ratio between NI and GI, expressed as a percentage. Regression analyzes were performed on these evaluated characteristics. A procedure to adjust the response curves was developed as a function of the amounts of $C$. procera biomass incorporated into the soil using the Table Curve software (JANDEL SCIENTIFIC, 1991).

\section{RESULTS AND DISCUSSION}

The results of the regression analyses of the determined characteristics on the crops and in the intercropped systems are shown in Table 1. The criteria: biological rationality, significance of the mean square of regression (MSR), the coefficient of determination (R2), and significance of the parameters of regression were met.

Table 1. Regression analyses (MSR) of the commercial productivity of carrot roots (CPCR), yield of cowpea green grains (YCoGG), partial land equivalent ratios for carrot (PLERC) and for cowpea (PLERCo), land equivalent ratio for the system (LER), score of the canonical variable (Z), gross income (GI), net income (NI), rate of return (RR) and of the net profit margin (NPM), and model determination coefficients $\left(\mathrm{R}^{2}\right)$, and values of model parameters tested.

\begin{tabular}{|c|c|c|c|c|c|c|}
\hline \multicolumn{4}{|c|}{ Sources of Variation } & \multicolumn{3}{|c|}{ Parameters } \\
\hline DF & $\begin{array}{l}\text { Regression } \\
2\end{array}$ & $\begin{array}{c}\text { Error } \\
2\end{array}$ & $\overline{\mathrm{R}^{2}}$ & $\mathrm{a}$ & $\mathrm{b}$ & $\mathrm{c}$ \\
\hline $\begin{array}{c}\text { Variables } \\
\text { CPCR } \\
\left(\mathrm{t} \mathrm{ha}^{-1}\right)\end{array}$ & $2.2018^{* *}$ & 0.0143 & $0.993^{* *}$ & $14.2044^{* *}$ & $0.00404^{*}$ & $-5.559 e-5^{*}$ \\
\hline $\begin{array}{l}\text { YCoGG } \\
\left(\mathrm{t} \mathrm{ha}^{-1}\right)\end{array}$ & $165798.3^{*}$ & 1765.97 & $0.989^{*}$ & $0.0022^{* *}$ & $-1.929 e-6^{*}$ & $2.747 \mathrm{e}-8^{*}$ \\
\hline PLERC & $0.0037^{* *}$ & $5.54 \mathrm{e}-10$ & $0.999^{* *}$ & $1.9805^{* *}$ & $-0.01796^{* *}$ & $0.000173^{* *}$ \\
\hline PLERCo & $0.5001^{* *}$ & $1.53 e-5$ & $0.999^{* *}$ & $-4.7614^{* *}$ & $0.18760^{* *}$ & $-0.00218^{* *}$ \\
\hline LER & $0.0779^{* *}$ & 0.00038 & $0.995^{* *}$ & $2.3144^{* *}$ & $-0.06550^{*}$ & $0.00075^{*}$ \\
\hline Z & $0.4517^{* *}$ & $5.81 \mathrm{e}-7$ & $0.999^{* *}$ & $1.1111^{* *}$ & $-0.03058^{* *}$ & $0.00033^{* *}$ \\
\hline $\begin{array}{c}\mathrm{GI} \\
\left(\mathrm{R} \$ \mathrm{ha}^{-1}\right)\end{array}$ & $45338749^{*}$ & 493670.74 & $0.989^{*}$ & $4.8887 \mathrm{e}-5^{* *}$ & $-1.013 e-6^{*}$ & $1.1430 \mathrm{e}-8^{*}$ \\
\hline $\begin{array}{c}\mathrm{NI} \\
\left(\mathrm{R} \$ \mathrm{ha}^{-1}\right)\end{array}$ & $22064576^{* *}$ & 123811.94 & $0.994^{* *}$ & $0.00017^{*}$ & $-5.466 e-6^{* *}$ & $6.731 \mathrm{e}-8^{*}$ \\
\hline RR & $0.038613207^{* *}$ & 0.0013242931 & $0.966^{*}$ & $0.7503^{* *}$ & $-0.00862^{* *}$ & $1.9624 \mathrm{e}-6^{*}$ \\
\hline $\begin{array}{l}\text { NPM } \\
(\%)\end{array}$ & $52.056^{*}$ & 0.57977 & $0.988^{*}$ & $0.0365^{* *}$ & $-0.00057^{* *}$ & $1.216 \mathrm{e}-7^{*}$ \\
\hline
\end{tabular}

$* *=\mathrm{P}<0.01 ; *=\mathrm{P}<0.05$.

The commercial productivity of carrot roots increased with increasing amounts of $C$. procera incorporated into the soil, up to the value of $17.31 \mathrm{t} \mathrm{ha}^{-1}$ using the $C$. procera amount of $48.05 \mathrm{t} \mathrm{ha}^{-1}$, decreasing then, up to the last added amount (Figure 2A). Similarly, an increase in yield of green grains of cowpea was observed with the amounts of $C$. procera up to the yield of $1293.99 \mathrm{~kg} \mathrm{ha}^{-1}$ in the amount of $45.51 \mathrm{t} \mathrm{ha}^{-1}$ of green manure, decreasing then until the last amount added (Figure 2B). It can be observed that these two characteristics were optimized before the highest dose of the green manure was incorporated, causing a decrease in their values after the maximum point. This decrease can be attributed to the law of maximum, where the excess of one nutrient in the soil may cause a toxic effect and/or decrease the effectiveness of others, leading to an overall reduction in production of the crops (ALMEIDA et al., 2015). 

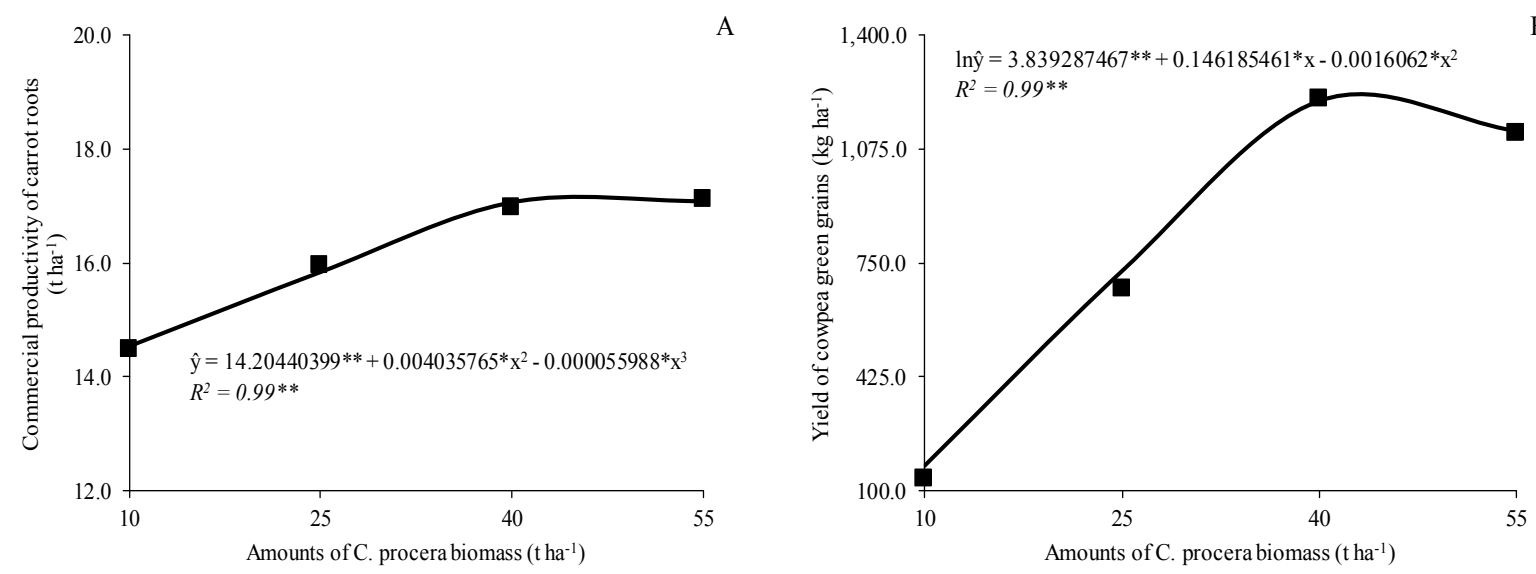

Figure 2. Commercial productivity of carrot roots (A) and yield of green grains of cowpea (B) in an intercropping system under different amounts of $C$. procera biomass incorporated into the soil.

The optimized response of these variables to the increased C. procera amounts can be attributed to the greater nutritional supply of the carrot and cowpea plants, an adequate synchronization between the decomposition and mineralization of the green manure added to the soil, and also to the time of greater nutritional requirement of the cultures (FONTANÉTTI et al., 2006).

In addition to this supply of nutrients provided by the increasing amounts of $C$. procera, this optimization of the crop productivities can be also due to the influence that the green manure exerted on the physical, chemical, and biological properties of the soil, since it presents conditioning effects and increases the capacity of the soil in storing nutrients necessary for the development of these plants, resulting in a higher yield of the crops (BATISTA et al., 2013; BATISTA et al., 2016).

The obtainment of the dose of productive efficiency maximum of the crops is of great value to family farmers who grow vegetable crops, since they can utilize this information about the dose that will provide the maximum yield of the carrot and cowpea crops when in an intercropping system.

There was also an increase in the land equivalent ratios of the carrot, cowpea, and of the intercropping system, and of the canonical variable $(\mathrm{Z})$, with increasing amounts of $C$. procera until the values of $0.66 ; 0.48 ; 1.12$ and 2.45 in the amounts of $51.98 ; 42.94 ; 43.39$ and $46.01 \mathrm{t} \mathrm{ha}^{-1}$ of $C$. procera were achieved, respectively, and decreasing then up to the last amount of the green manure added to the soil (Figure 3). This decrease in the agronomic indices is not only due to the law of maximum but also due the high competition between the cultures for available environmental resources, namely light, water, nutrients, and carbon dioxide $\left(\mathrm{CO}_{2}\right)$, from the point of maximum agronomic efficiency of the intercropped system, thus reducing its biological efficiency (OLIVEIRA et al., 2017; ALMEIDA et al., 2015).

This optimization and efficiency of the intercropping system obtained in these maximum values are due to the better use of the environmental resources by the vegetable crops, as well as by the complementarity between the component cultures.

This situation can also be explained by observations from Caballero, Goicoechea and Hermaiz (1995), where it states that when the LER in this maximum value was greater than 1.0 , the intercropping will favor the growth and production of the component cultures. In the same sense, Bezerra Neto et al. (2010) reported that an intercropping system is considered efficient when the LER value is higher than 1.0 , once the commercial standard of the crops is reached. 

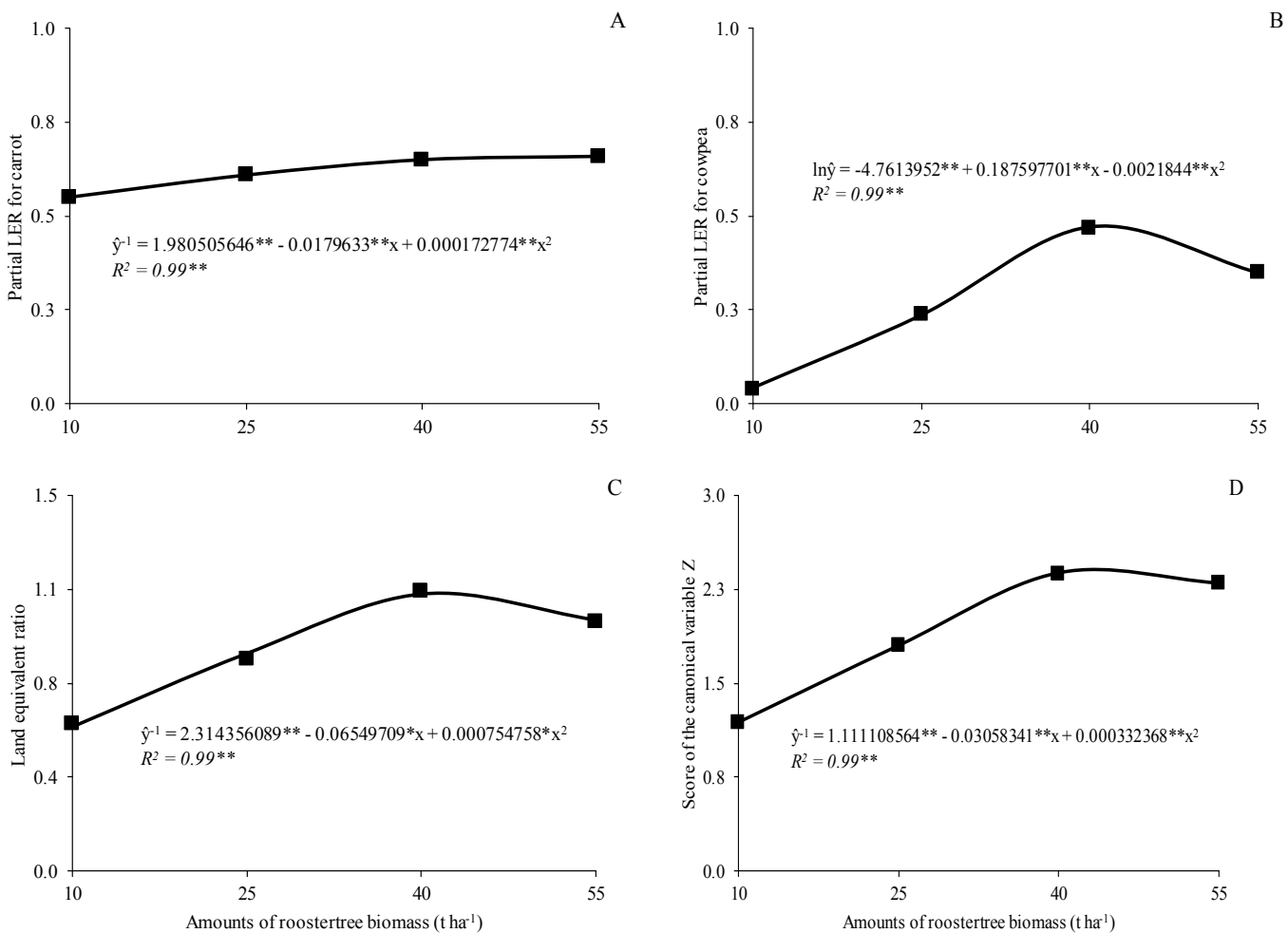

Figure 3. Partial land equivalent ratio for carrot (A), for cowpea (B) and for the system (C), and the score of the canonical variable Z (D) under different amounts of $C$. procera biomass incorporated into the soil.

Pereira et al. (2016) worked with intercropping systems of radish and cowpea fertilized with $C$. procera, and obtained an agronomic advantage in the association with maximum value of the canonical variable score of 10.21 with the incorporation to the soil of $50.01 \mathrm{t} \mathrm{ha}^{-}$ ${ }^{1}$ of $C$. procera, using a dose which was higher than that optimized in the carrot and cowpea intercropping in this study, which was $46.01 \mathrm{t} \mathrm{ha}^{-1}$. This difference is due to the variations sponsored by the radish in relation to carrot. However, in carrot and cowpea intercropping systems fertilized with $C$. procera, Favacho et al. (2017) obtained a maximum agronomic efficiency measured by the LER, with the value of 1.99 in dose of C. procera of $30.93 \mathrm{t} \mathrm{ha}^{-1}$ incorporated into the soil, at a dose lower than what was obtained in this study.

The total costs of production obtained in the carrot and cowpea intercropping systems in the $C$. procera quantities tested are presented in Table 2. It can be observed that the highest costs were recorded with inputs: seeds, substrate, the plastic for solarization, with the labor used for the handling of green manure preparation, in services performed in the experimental area and with the crops, and with the energy to pump the water to the irrigation system for the research. These costs were followed by fixed costs with facilities, materials, and with the costs of opportunities such as the remuneration of the land and fixed capital (Table 2).

Table 2. Total costs in the production of one hectare of carrot $\mathrm{x}$ cowpea as a function of C. procera amounts tested.

\begin{tabular}{|c|c|c|c|c|c|c|}
\hline \multirow{2}{*}{ Discrimination } & \multirow{2}{*}{ Unity } & \multirow{2}{*}{ Amount } & \multicolumn{4}{|c|}{ Amounts of $C$. procera biomass } \\
\hline & & & $10 \mathrm{t} \mathrm{ha-}^{1}$ & 25 tha- $^{1}$ & 40 tha- $^{-1}$ & 55 tha- $^{1}$ \\
\hline A. Variable cost & & & 15.460 .14 & 17.055.94 & 18.671.94 & 20.348 .54 \\
\hline A.1. Inputs & & & 8.726 .80 & 8.726 .80 & 8.726 .80 & 8.726 .80 \\
\hline Carrot seeds cv. Brasília & $\mathrm{kg}$ & 12 & 960.00 & 960.00 & 960.00 & 960.00 \\
\hline $\begin{array}{l}\text { Cowpea seeds cv. BRS Itaim } \\
\text { Substrate of coconut fiber }\end{array}$ & & 20 & 56.60 & 56.60 & 56.60 & 56.60 \\
\hline (Golden Mix) & $22 \mathrm{~kg}$ bag & 10 & 899.00 & 899.00 & 899.00 & 899.00 \\
\hline Plastic Coil for solarization & $\mathrm{m}$ & 2064 & 6.811 .20 & 6.811 .20 & 6.811 .20 & 6.811 .20 \\
\hline A.2. Labor & & & 6.150 .00 & 7.730 .00 & 9.330 .00 & 10.990 .00 \\
\hline A.2.1 - Costs with green manure & & & 1.360 .00 & 2.880 .00 & 4.420 .00 & 6.020 .00 \\
\hline
\end{tabular}

*Estimate based on the useful life of the asset, its market value and of the time of its use during the research. 
Table 2. continued.

\begin{tabular}{|c|c|c|c|c|c|c|}
\hline \multirow{2}{*}{ Discrimination } & \multirow{2}{*}{ Unity } & \multirow{2}{*}{ Amount } & \multicolumn{4}{|c|}{ Amounts of $C$. procera biomass } \\
\hline & & & 10 tha- $^{1}$ & 25 tha- $^{-1}$ & 40 tha- ${ }^{1}$ & 55 tha- $^{-1}$ \\
\hline Cutting & day $\operatorname{man}^{-1}$ & 33 & 990.00 & 2.460 .00 & 3.900 .00 & 5.400 .00 \\
\hline Transport & freight & 1 & 60.00 & 60.00 & 60.00 & 60.00 \\
\hline Grinding & day $\operatorname{man}^{-1}$ & 2 & 100.00 & 150.00 & 250.00 & 350.00 \\
\hline Drying & day $\operatorname{man}^{-1}$ & 6 & 180.00 & 180.00 & 180.00 & 180.00 \\
\hline Bagging & day $\operatorname{man}^{-1}$ & 1 & 30.00 & 30.00 & 30.00 & 30.00 \\
\hline A.2.2 - Costs with other services & & & 4.790 .00 & 4.850 .00 & 4.910 .00 & 4.970 .00 \\
\hline Cleaning of the land & tractor hour & 1 & 70.00 & 70.00 & 70.00 & 70.00 \\
\hline Plowing & tractor hour & 2 & 140.00 & 140.00 & 140.00 & 140.00 \\
\hline Harrowing & tractor hour & 2 & 140.00 & 140.00 & 140.00 & 140.00 \\
\hline Manufacture of the beds & day $\operatorname{man}^{-1}$ & 40 & 1.200 .00 & 1.200 .00 & 1.200 .00 & 1.200 .00 \\
\hline Distribution and manure incorporation & day $\operatorname{man}^{-1}$ & 3 & 90.00 & 150.00 & 210.00 & 270.00 \\
\hline Planting & day $\operatorname{man}^{-1}$ & 35 & 1.050 .00 & 1.050 .00 & 1.050 .00 & 1.050 .00 \\
\hline Thinning & day $\operatorname{man}^{-1}$ & 25 & 750.00 & 750.00 & 750.00 & 750.00 \\
\hline Hand weeding & day $\operatorname{man}^{-1}$ & 10 & 300.00 & 300.00 & 300.00 & 300.00 \\
\hline Harvest & day $\operatorname{man}^{-1}$ & 25 & 750.00 & 750.00 & 750.00 & 750.00 \\
\hline Transport & day $\operatorname{man}^{-1}$ & 10 & 300.00 & 300.00 & 300.00 & 300.00 \\
\hline A.3. Energy & & & & & & \\
\hline Energy used for irrigation & $\mathrm{Kw} / \mathrm{h}$ & 981.99 & 212.28 & 212.28 & 212.28 & 212.28 \\
\hline $\begin{array}{l}\text { A.4. Other expenses } \\
1 \% \text { on the values of (A.1), (A.2) }\end{array}$ & & & 150.89 & 166.69 & 182.69 & 199.29 \\
\hline and (A.3) & & & 150.89 & 166.69 & 182.69 & 199.29 \\
\hline $\begin{array}{l}\text { A.5. Maintenance and Conservation } \\
1 \% \text { per year on the value of buildings }\end{array}$ & & & 220.17 & 220.17 & 220.17 & 220.17 \\
\hline $\begin{array}{l}\text { (shed and well) } \\
5 \% \text { per year on the value of the forage }\end{array}$ & $\%$ & 1 & 33.00 & 33.00 & 33.00 & 33.00 \\
\hline machine & $\%$ & 5 & 16.50 & 16.50 & 16.50 & 16.50 \\
\hline $\begin{array}{l}\text { irrigation system } \\
\text { irne value of the }\end{array}$ & $\%$ & 7 & 170.67 & 170.67 & 170.67 & 170.67 \\
\hline B - Fixed costs & & & 1.080 .75 & 1.080 .75 & 1.080 .75 & 1.080 .75 \\
\hline B.1. Depreciation* & & & 470.75 & 470.75 & 470.75 & 470.75 \\
\hline Submerged pump & & & 138.80 & 138.80 & 138.80 & 138.80 \\
\hline Pipes of PVC 2 " & & & 12.45 & 12.45 & 12.45 & 12.45 \\
\hline Well & & & 25.00 & 25.00 & 25.00 & 25.00 \\
\hline Micro sprinklers & & & 130.00 & 130.00 & 130.00 & 130.00 \\
\hline Connections of PVC & & & 39.50 & 39.50 & 39.50 & 39.50 \\
\hline Shed & & & 125.00 & 125.00 & 125.00 & 125.00 \\
\hline B.2. Taxes and fees & & & 10.00 & 10.00 & 10.00 & 10.00 \\
\hline Rural territorial tax & ha & 1 & 10.00 & 10.00 & 10.00 & 10.00 \\
\hline B.3. Fixed labor & & & 600.00 & 600.00 & 600.00 & 600.00 \\
\hline Aux. Administração & $\begin{array}{l}\text { minimum } \\
\text { wage }\end{array}$ & 1 & 600.00 & 600.00 & 600.00 & 600.00 \\
\hline C. Opportunity Costs & & & 224.98 & 224.98 & 224.98 & 224.98 \\
\hline C.1. Remuneration of land & & & 100.00 & 100.00 & 100.00 & 100.00 \\
\hline Leasing & ha & 1 & 100.00 & 100.00 & 100.00 & 100.00 \\
\hline $\begin{array}{l}\text { C.2. Remuneration of Fixed } \\
\text { Capital }(6 \% \text { year } \\
-1)\end{array}$ & & & 124.98 & 124.98 & 124.98 & 124.98 \\
\hline $\begin{array}{l}\text { Infrastructure, machinery and } \\
\text { equipment }\end{array}$ & $\%$ & 6 & 124.98 & 124.98 & 124.98 & 124.98 \\
\hline $\begin{array}{l}\text { Total Costs (Variable cost }+ \\
\text { Fixed costs }+ \text { Opportunity costs) }\end{array}$ & & & 16.765 .87 & 18.361.67 & 19.977 .67 & 21.654.27 \\
\hline
\end{tabular}

*Estimate based on the useful life of the asset, its market value and of the time of its use during the research.

Rev. Caatinga, Mossoró, v. 32, n. 1, p. 62 - 71, jan. - mar., 2019 
The economic indicators of GI, NI, RR, and profit margin increased with the increase in the amount of $C$. procera incorporated into the soil, up to the maximum values of $\mathrm{R} \$ 37,815.33 ; \mathrm{R} \$$
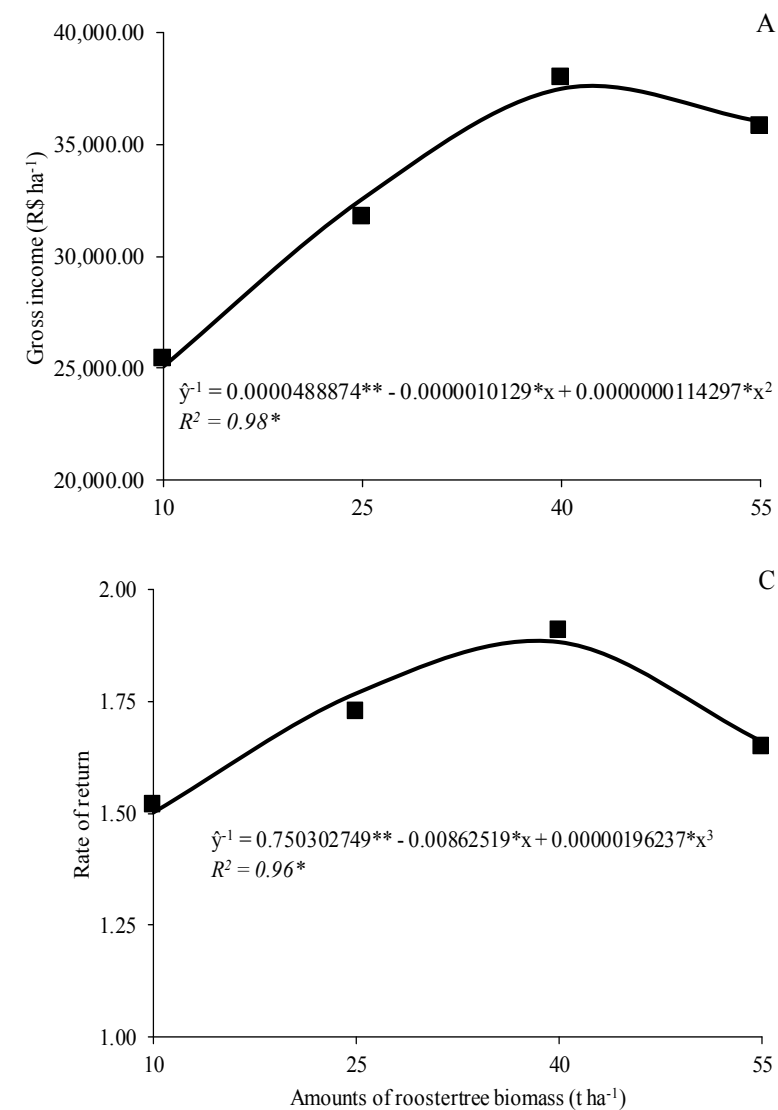

$17,856.43 ; 1.89$ and $46.81 \%$, at green manure doses of $44.31 ; 40.60 ; 38.28$ and $39.60 \mathrm{t} \mathrm{ha}^{-1}$, then decreasing until the addition of the last quantity added to the soil (Figure 4).
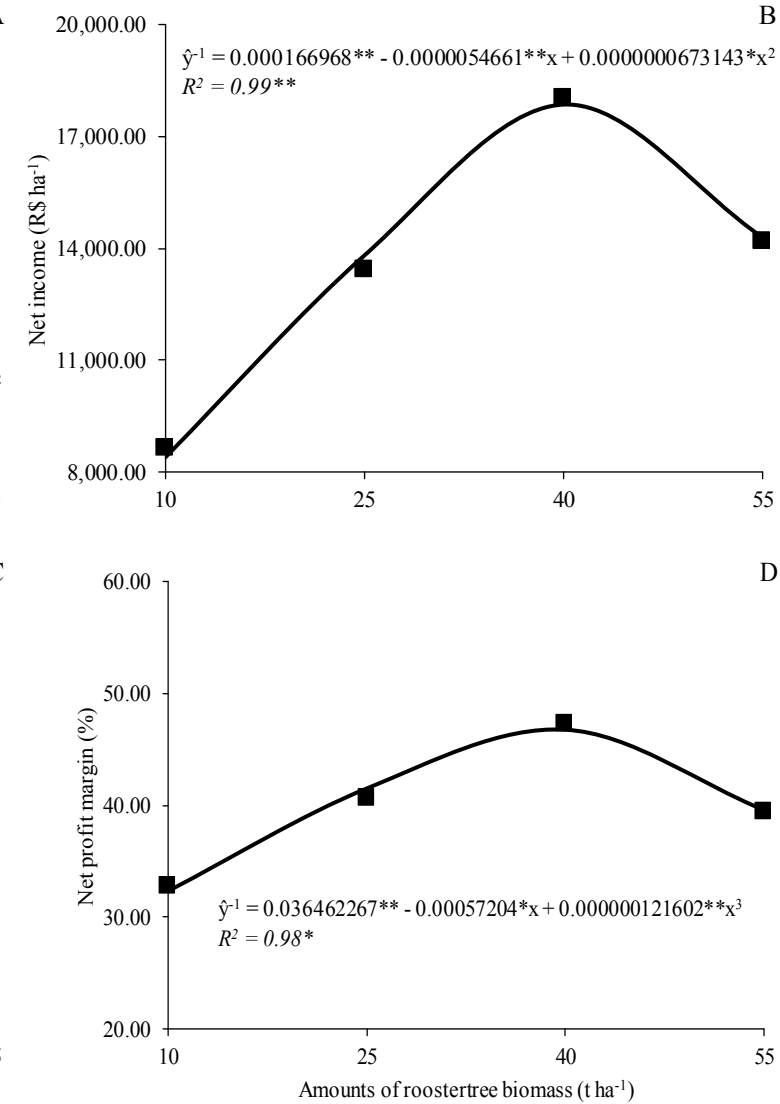

Figure 4. Gross income (A), net income (B), rate of return (C) and profit margin (D) of the carrot and cowpea intercropping under different amounts of $C$. procera biomass incorporated into the soil.

The results of these economic indicators found that the agronomic-biological superiority in all of the quantities of $C$. procera tested translated into economic terms in relation to the single cultures via the optimal use of the environmental resources. According to Beltrão et al. (1984), NI is one of the indicators that better expresses the economic value of the intercropped system over the GI, because production costs are deducted. The expenses that most affected these production costs were those with inputs, labor, energy, maintenance, and conservation of the facilities and equipment. If these intercropping systems are conducted by family farmers where the labor force in the production of crops is carried out by the family itself, this means that the expense of this labor force would become an extra profit for the family farmer, thus the overall NI of the intercropped production systems would increase. In this research, NI was used to express the economic efficiency of the carrot-cowpea intercropping.

Research evaluating intercropping systems of carrot and cowpea fertilized with $C$. procera grown in the same experimental area has provided gross and net incomes and net profit margin in the point of economic efficiency maximum of $\mathrm{R} \$ 43,536.16$, $\mathrm{R} \$$ $27,998.94$ and $65,34 \%$, in the quantities of $C$. procera of $36.45 ; 29.48$; and $26.00 \mathrm{t} \mathrm{ha} \mathrm{ha}^{-1}$ (FAVACHO, 2015), indicators that are slightly higher than those obtained in this research, which were approximately $\mathrm{R} \$ 37,815.33$; R $\$ 17,856.43$; and $46.96 \%$ in green manure doses of $44.31 ; 40.60$; and $40.88 \mathrm{tha}^{-1}$.

\section{CONCLUSION}

The optimization of the commercial productivity of carrot roots in intercropping with cowpea of $17.31 \mathrm{t} \mathrm{ha}^{-1}$ was obtained with the incorporation of $48.05 \mathrm{t} \mathrm{ha}^{-1}$ of C. procera, while the optimization of green grain yield of cowpea intercropped with carrot of $1293.99 \mathrm{~kg} \mathrm{ha}^{-1}$ was reached with the approximate amount of $45.51 \mathrm{t} \mathrm{ha}^{-1}$ of the green manure added to the soil.

The maximum agronomic efficiency of the carrot $x$ cowpea intercropping was achieved with the land equivalent ratio of 1.12 , using $43.39 \mathrm{t} \mathrm{ha}^{-1}$ of $C$. procera biomass incorporated into the soil. 
The maximum economic efficiency of the carrot and cowpea association was obtained with the net income of $\mathrm{R} \$ 17,856.43$, in the amount of $40.60 \mathrm{t} \mathrm{ha}^{-1}$ of $C$. procera biomass added to the soil.

The $C$. procera species used as green manure proved to be viable for the agro-economic performance of the carrot and cowpea intercropping.

\section{ACKNOWLEDGEMENTS}

Special thanks are due to the Coordenação de Aperfeiçoamento de Pessoal de Nível Superior (CAPES) for their financial support of this research and to the research group that develops technologies for growing vegetables on family farms.

\section{REFERENCES}

ALMEIDA, A. E. S. et al. Eficiência agronômica do consórcio alface-rúcula fertilizado com flor-de-seda. Revista Caatinga, v. 28, n. 3, p. 79-85, 2015.

BATISTA, M. A. V. et al. Atributos microbiológicos do solo e produtividade de rabanete influenciados pelo uso de espécies espontâneas. Horticultura Brasileira, v. 31, n. 4, p. 587-594, 2013.

BATISTA, M. A. V. et al. Atributos de solo-planta e de produção de beterraba influ-enciados pela adubação com espécies da Caatinga. Horticultura Brasileira, v. 34, n. 1, p. 12-19, 2016.

BELtrão, N. E. M. et al. Comparação entre indicadores agroeconômicos de avaliação de agroecossistemas consorciados e solteiros envolvendo algodão "upland" e feijão "caupi". Campina Grande: EMBRAPA-CNPA, 1984. 21 p. (Boletim de pesquisa, 15).

BEZERRA NETO, F. et al. Evaluation of yield advantage indexes in carrot-lettuce intercropping systems. Interciencia, v. 35, n. 1, p. 59-64, 2010.

CABALLERO, R.; GOICOECHEA, E. L.; HERMAIZ, P. J. Forage yields and quality of common vetch and oat sown at varying seeding ratios and seeding rates of common vetch. Field Crops Research, v. 41, n. 2, p. 135-140, 1995.

CALEGARI, A. et al. Aspectos gerais da adubação verde. In: COSTA, M. B. B. (Ed.). Adubação verde no sul do Brasil. 2. ed. Rio de Janeiro: AS-PTA, 1993. p. $1-56$.

CASTRO, C. M. de et al. Adubação verde como fonte de nitrogênio para a cultura da berinjela em sistema orgânico. Pesquisa Agropecuária Brasileira, v. 39, n. 8, p. 779-785, 2004.

COSTA, A. P. et al. Intercropping of carrot $\mathrm{x}$ cowpea-vegetables: evaluation of cultivar combinations fertilized with roostertree. Revista Caatinga, v. 30, n. 3, p. 633-641, 2017.

DELARMELINDA, E. A. et al. Adubação verde e alterações nas características químicas de um Cambissolo na região de Ji-Paraná-RO. Acta Amazônica, v. 40, n. 3, p. 625-628, 2010.

FAVACHO, F. S. Eficiência agroeconômica do consórcio cenoura $x$ caupi-hortaliça em função de quantidades de biomassa de flor-de-seda e arranjos espaciais. 2015. $73 \mathrm{f}$. Tese (Doutorado em Fitotecnia: Área de Concentração em Práticas Culturais) - Universidade Federal Rural do SemiÁrido, Mossoró, 2015.

FAVACHO, F. S. et al. Productive and economic efficiency of carrot intercropped with cowpea vegetable resulting from green manure and different spatial arrangements. Revista Ciência Agronômica, v. 48, n. 2, p. 337-446, 2017.

FONTANÉTTI, A. et al. Adubação verde na produção orgânica de alface americana e repolho. Horticultura Brasileira, v. 24, n. 2, p. 146-150, 2006.

JANDEL SCIENTIFIC. Table curve: curve fitting software. Corte Madera, CA: Jandel Scientific, 1991. $280 \mathrm{p}$.

NOVAIS, R. F. et al. Fertilidade do solo. In: MEURER, E. J. (Ed.). Fatores que influenciam o crescimento e o desenvolvimento das plantas. Viçosa: SBCS, 2007. p. 65-90.

OLIVEIRA, L. A. A. et al. Agro-economic efficiency of polycultures of arugula-carrot-lettuce fertilized with roostertree at different population density proportions. Revista Brasileira de Engenharia Agrícola e Ambiental, v. 21, n. 11, p. 791-797, 2017.

OLIVEIRA, M. K. T. et al. 2012. Desempenho agroeconômico da cenoura adubada com jitirana (Merremia aegyptia). Horticultura Brasileira, v. 30, n. 3, p. 433-439, 2012.

PEREIRA, M. F. S. et al. Productive performance of cowpea-radish intercroppings under different amounts of rooster tree biomass incorporated into the soil. Revista Brasileira de Engenharia Agrícola e Ambiental, v. 20, n. 11, p. 965-971, 2016. 
PORTO, V. C. N. et al. Combination of lettuce and rocket cultivars in two cultures intercropped with carrots. Horticultura Brasileira, v. 29, n. 3, p. 404411, 2011.

RIBEIRO, G. M. et al. Productive performance of carrot and cowpea intercropping system under different spatial arrangements and population densities. Revista Caatinga, v. 31, n. 1, p. 19-27, 2018.

RUSINAMHODZI, L. et al. Maize-grain legume intercropping is an attractive option for ecological intensification that reduces climatic risk for smallholder farmers in central Mozambique. Field Crops Research, v. 136, n. 1, p. 12-22, 2012.

SANTOS, J. F. et al. Novas variedades de caupi para microrregião do Brejo Paraibano. Tecnologia \& Ciência Agropecuária, v. 3, n. 3, p. 7-12, 2009.

SOUZA, A. R. E. et al. Agronomic performance of carrot fertilized with roostertree [Calotropis procera (Ait.) R. Br.] in two growing seasons. Bioscience Journal, v. 33, n. 6, p. 1401-1411, 2017a.

SOUZA, E. G. F. et al. Production of lettuce under green manuring with Calotropis procera in two cultivation seasons. Revista Caatinga, v. 30, n. 2, p. 391-400, 2017b.

SOUZA, E. G. F. et al. Green manuring with Calotropis procera for the production of coriander in two growing seasons. Ciência e Agrotecnologia, v. 41, n. 5 , p. $533-542,2017$ c.

VIEIRA, F. A. Doses de máxima eficiência física e econômica de flor-de-seda no rendimento de caupi-hortaliça. 2014. 55f. Dissertação (Mestrado em Fitotecnia: Área de Concentração em Práticas Culturais) - Universidade Federal Rural do SemiÁrido (UFERSA), Mossoró, 2014. 